\title{
The Grey Relational Analysis of Quality Investigation of Concrete Containing Solar PV Cells
}

\author{
Hui-Mi Hsu ${ }^{1}$, An Cheng ${ }^{1, \text { a }}$, Sao-Jeng Chao ${ }^{1}$, Jia-Ruey Chang ${ }^{2}$, Li-Wei Teng ${ }^{3}$, Sung-Ching Chen ${ }^{3}$ \\ ${ }^{1}$ Dept. of Civil Engineering, National Ilan University, Yilan 260, Taiwan \\ ${ }^{2}$ Center for Sustainable Development, National Ilan University, Yilan 260, Taiwan \\ ${ }^{3}$ Dept. of Harbor and River Engineering, National Taiwan Ocean University, Keelung 202, Taiwan
}

\begin{abstract}
The construction industry through the use of less polluting green energy technology is already imminent and more had to do, and continue to improve as the development of green energy. Concrete is the most common-used construction material in the modern world. Traditional concrete is a composite, which is made of aggregate, Portland cement and water. Production of Portland cement consumes large amount of energy and releases lots of carbon dioxide, nevertheless, the developing of sustainable society means more urgent and important to search for new cementitious materials to replace Portland cement in future constructions. The research employs Taguchi method and Grey Relational Analysis (GRA) to invetigate the performance of alkali activated silica fume concrete in which amorphous silicon solar cells are ground and added into the mixture in three-phase analysis. Firstly, this study used Taguchi's orthogonal array to evaluate the influence of the control factors and identify the important factors influencing quality characteristics. Secondly, all normalizing experiment variables ranked the grey relational grades of multi-quality characteristics. Finally, this study integrated the Taguchi method and the equal weights by using GRA to establish both equal and entropy weight-based grey relational values.
\end{abstract}

\section{Introduction}

Alkali-activation of slag, fly ash and other aluminosilicate materials have been intensively investigated during the last decades [1]. In comparison with conventional Portland cement-based composites these materials offer excellent durability in chemically aggressive environment, high compressive strength, lower basic creep, or environmental benefits. The objective of this paper is to identify the key factors influencing the performance of alkali activated silica fume concrete in which amorphous silicon solar cells are ground and added into the mixture the properties of alkali-activated materials in solar PV cells.

In previous studies [2-4], we had demonstrated the study results of general quality of concrete blended with waste solar PV cells. The use of ground solar cells on the mechanical properties and durability of cncrete had been investigated. This research attempts further to invetigae the quality of alkali activated concrete conaining the ground amorphous silicon solar cells. Utilization of Taguchi method is to minimize the experiment number using standard orthogonal array and Signal to Noise ratio $(\mathrm{S} / \mathrm{N})$ [5]. Usually it can only consider single quality characteristics, while GRA is usually employed to deal with multi-quality characteristics. Thus, combining these two methods could enhance quality and reliability [6-8]. The Taguchi method and GRA were employed in threephase analysis. Firstly, this study used Taguchi's orthogonal array to evaluate the influence of the control factors and identify the important factors influencing quality characteristics. Secondly, all normalizing experiment variables ranked the grey relational grades of multi-quality characteristics. Finally, this study integrated the Taguchi method and the entropy weights by using GRA to establish entropy weight-based grey relational values.

\section{Experiments}

1. Compressive strength test: Compressive strength testing is crutial to understand the stength capacity of a concrete specimen. Compressive strength test of the specimens is conducted according to ASTM C109-13【Standard Test Method for Compressive Strength of Hydraulic Cement Mortars 】 with a specimen size, $50 \times 50 \times 50 \mathrm{~mm}$.

2. Resistivity test: Surface resistivity measurement may provide very useful information about the state of a concrete structure. It has been proven to be directly linked to the likelihood of corrosion and the corrosion rate, and there is a direct correlation between resistivity and chloride diffusion rate and even to determination of early compressive strength. Concrete resistivity measurements on cylindrical test samples with a size of $100 \times 200 \mathrm{~mm}$ performed with the four-point Wenner array probe technique

\footnotetext{
${ }^{\mathrm{a}}$ Corresponding author: ancheng@ $\mathrm{niu}$.edu.tw
} 
3. Water absorption test: Absorption can be described as the ability to take in water by means of capillary suction. As such, water absorption has been used as an important factor for quantifying the durability of cementitious systems. Water absorption was made in accordance with ASTM C642-13 【 Standard Test Method for Density, Absorption, and Voids in Hardened Concrete 】 with a cylinder size of $100 \times 50 \mathrm{~mm}$.

4. Permeability test: The water permeability of concrete at the surface is a key factor in determining the durability of concrete structures. A reliable permeability test of the concrete cover is therefore crucial, namely the CRD-C48-92 standard test method for water permeability of concrete with a cylinder size of $100 \times 50 \mathrm{~mm}$.

\section{Taguchi method}

Taguchi method is a design and analysis of experiments for the purpose of designing and improving quality. Taguchi method primarily involves orthogonal arrays and $\mathrm{S} / \mathrm{N}$ ratio. Orthogonal arrays can reduce the number of experiments, and thus, overall costs. In Taguchi method, $\mathrm{S} / \mathrm{N}$ ratio is used to measure the deviation of the quality characteristics from the desired value. The $\mathrm{S} / \mathrm{N}$ ratio for each process parameter is calculated based on $\mathrm{S} / \mathrm{N}$ analysis function. A larger $\mathrm{S} / \mathrm{N}$ ratio is normally consistent with better quality characteristics. Quality characteristics can be divided into larger-the-better (LTB), smaller-the-better (STB), and nominal-the-best (NTB). This study set compressive strength and resistivity as an LTB characteristic and water absorption and permeability as STB characteristics in the investigation of single quality characteristics.

\section{Orthogonal array}

An orthogonal array is used to reduce the number of experiments, and thus, overall costs. To determine the multi-quality characteristics, this study adopted the materials used in previous studies [2-5] as the control factors in experiments. At such, a full factorial experiments with seven control factors \& three level would produce Taguchi's $L_{18}\left(2^{1} \times 3^{6}\right)$ orthogonal array with only 18 experiments. Responses to the factors were then analyzed.

\section{Analysis of variance}

The use of $\mathrm{S} / \mathrm{N}$ ratios provides only the degree of influence that the factor levels exert on the experiment.
However, ANOVA enables a further evaluation of the contribution of each factor and determines its importance. ANOVA and F-test were performed to statistically see the control factors significant process and percent contribution to the experiment. In the process, the $\mathrm{S} / \mathrm{N}$ ratio sum of squares for each factor is determined to calculate the between-group variability and then F-test and contribution ratio can be calculated, respectively [9].

\section{Grey relational analysis}

Grey Relational Analysis (GRA), a normalization evaluation technique is extended to solve the complicated multi-performance characteristics optimization effectively [10]. The grey theory is based on the random uncertainty of small samples which developed into an evaluation technique to solve certain problems of system that are complex and having incomplete information. By investigating a small amount of data and multiple characteristics, reference series can be derived from different series of data. Deriving the overall relation grade of the series or the relational grades of the individual series factor changes can also integrate the data of multiple independent quality characteristics into a single relational order of optimal multi-quality characteristics. This prevents overlooking many quality characteristics for the sake of one. The results can be compared with the order obtained using Taguchi methods described as above.

\section{Results}

In the GRA, the quality characteristics (compressive strength, resistivity, water absorption, and permeability results) were converted into a single optimal order combination. The units and values of the quality characteristics in the analysis varied; therefore, grey relational generation was normalize the corresponding values between 0 and 1 . Table 1 and 2 present the grey relational coefficients and grey relational orders in which the grey relational grades were respectively divided into equally weighted grades and entropy weight-based grades prior to ranking. As the name suggests, equal weights indicate that the weight values were equally distributed among the quality characteristics. Entropy weights, on the other hand, were based on the differences in data related to quality characteristics. The entropy weights for compressive strength, resistivity, water absorption, and permeability were $0.3216,0.3364,0.3420$ and 0.1867 , respectively. The higher entropy weight for compressive strength was caused by the greater differences in the experimental data. Therefore, the grey relational coefficient of the permeability test is the smallest value due to its least differences.

Table 1. Grey relational coefficients and Equal weights. 


\begin{tabular}{|c|c|c|c|c|c|c|}
\hline \multirow{2}{*}{ Experiment } & \multicolumn{3}{|c|}{ Grey relational coefficients } & \multicolumn{2}{c|}{ Equal weights } \\
\cline { 2 - 7 } & $\begin{array}{c}\text { Compressive strength } \\
\text { test(\%) }\end{array}$ & $\begin{array}{c}\text { Resistivity } \\
\text { test(\%) }\end{array}$ & $\begin{array}{c}\text { Water absorption } \\
\text { test(\%) }\end{array}$ & $\begin{array}{c}\text { Permeability } \\
\text { test(\%) }\end{array}$ & $\begin{array}{c}\text { Grey relational } \\
\text { grade }\end{array}$ & Rank \\
\hline $\mathbf{1}$ & 1.0000 & 1.0000 & 1.0000 & 1.0000 & 1.0000 & 1 \\
\hline $\mathbf{2}$ & 0.5135 & 0.6903 & 0.5403 & 0.6051 & 0.5873 & 7 \\
\hline $\mathbf{3}$ & 0.4979 & 0.5220 & 0.5042 & 0.4803 & 0.5011 & 10 \\
\hline $\mathbf{4}$ & 0.4720 & 0.5823 & 0.5242 & 0.4275 & 0.5015 & 9 \\
\hline $\mathbf{5}$ & 0.4966 & 0.5214 & 0.4955 & 0.5096 & 0.5058 & 8 \\
\hline $\mathbf{6}$ & 0.6512 & 0.7643 & 0.6811 & 0.7516 & 0.7120 & 4 \\
\hline $\mathbf{7}$ & 0.4496 & 0.4574 & 0.4111 & 0.4051 & 0.4308 & 13 \\
\hline $\mathbf{8}$ & 0.4922 & 0.4502 & 0.4513 & 0.4579 & 0.4629 & 11 \\
\hline $\mathbf{9}$ & 0.3333 & 0.3333 & 0.3333 & 0.3333 & 0.3333 & 18 \\
\hline $\mathbf{1 0}$ & 0.6093 & 0.5996 & 0.5672 & 0.7390 & 0.6288 & 6 \\
\hline $\mathbf{1 1}$ & 0.8297 & 0.9134 & 0.9937 & 0.9973 & 0.9335 & 2 \\
\hline $\mathbf{1 2}$ & 0.7397 & 0.7929 & 0.8966 & 0.9779 & 0.8518 & 3 \\
\hline $\mathbf{1 3}$ & 0.5735 & 0.7544 & 0.6114 & 0.7061 & 0.6614 & 5 \\
\hline $\mathbf{1 4}$ & 0.4022 & 0.3985 & 0.3832 & 0.3643 & 0.3870 & 17 \\
\hline $\mathbf{1 5}$ & 0.4624 & 0.4460 & 0.4506 & 0.4262 & 0.4463 & 12 \\
\hline $\mathbf{1 6}$ & 0.4349 & 0.4359 & 0.3847 & 0.3778 & 0.4083 & 15 \\
\hline $\mathbf{1 7}$ & 0.4412 & 0.4443 & 0.4405 & 0.3744 & 0.4251 & 14 \\
\hline $\mathbf{1 8}$ & 0.3888 & 0.4727 & 0.3849 & 0.3574 & 0.4009 & 16 \\
\hline
\end{tabular}

Table 2. Grey relational coefficients and entropy weights.

\begin{tabular}{|c|c|c|c|c|c|c|}
\hline \multirow{3}{*}{ Experiment } & \multicolumn{4}{|c|}{ Grey relational coefficients } & \multicolumn{2}{|c|}{ Entropy weights } \\
\hline & $\begin{array}{c}\text { Compressive } \\
\text { strength test }(\%) \\
\end{array}$ & $\begin{array}{l}\text { Resistivity } \\
\text { test(\%) }\end{array}$ & $\begin{array}{c}\text { Water absorption } \\
\text { test }(\%)\end{array}$ & $\begin{array}{c}\text { Permeability } \\
\text { test }(\%)\end{array}$ & \multirow{2}{*}{$\begin{array}{l}\text { Grey relational } \\
\text { grade }\end{array}$} & \multirow[t]{2}{*}{ Rank } \\
\hline & 0.3216 & 0.3364 & 0.3420 & 0.1867 & & \\
\hline 1 & 1.0000 & 1.0000 & 1.0000 & 1.0000 & 1.1867 & 1 \\
\hline 2 & 0.5135 & 0.6903 & 0.5403 & 0.6051 & 0.6951 & 7 \\
\hline 3 & 0.4979 & 0.5220 & 0.5042 & 0.4803 & 0.5978 & 10 \\
\hline 4 & 0.4720 & 0.5823 & 0.5242 & 0.4275 & 0.6068 & 8 \\
\hline 5 & 0.4966 & 0.5214 & 0.4955 & 0.5096 & 0.5997 & 9 \\
\hline 6 & 0.6512 & 0.7643 & 0.6811 & 0.7516 & 0.8398 & 4 \\
\hline 7 & 0.4496 & 0.4574 & 0.4111 & 0.4051 & 0.5147 & 13 \\
\hline 8 & 0.4922 & 0.4502 & 0.4513 & 0.4579 & 0.5496 & 11 \\
\hline 9 & 0.3333 & 0.3333 & 0.3333 & 0.3333 & 0.3956 & 18 \\
\hline 10 & 0.6093 & 0.5996 & 0.5672 & 0.7390 & 0.7296 & 6 \\
\hline 11 & 0.8297 & 0.9134 & 0.9937 & 0.9973 & 1.1002 & 2 \\
\hline 12 & 0.7397 & 0.7929 & 0.8966 & 0.9779 & 0.9939 & 3 \\
\hline 13 & 0.5735 & 0.7544 & 0.6114 & 0.7061 & 0.7792 & 5 \\
\hline 14 & 0.4022 & 0.3985 & 0.3832 & 0.3643 & 0.4625 & 17 \\
\hline 15 & 0.4624 & 0.4460 & 0.4506 & 0.4262 & 0.5325 & 12 \\
\hline 16 & 0.4349 & 0.4359 & 0.3847 & 0.3778 & 0.4886 & 15 \\
\hline 17 & 0.4412 & 0.4443 & 0.4405 & 0.3744 & 0.5119 & 14 \\
\hline 18 & 0.3888 & 0.4727 & 0.3849 & 0.3574 & 0.4824 & 16 \\
\hline
\end{tabular}

\section{Conclusions}

In this article, utilization of Taguchi method is to minimize the experiment number using standard orthogonal array and Signal to Noise ratio $(\mathrm{S} / \mathrm{N})$. Meanwhile, the Taguchi method and GRA were employed in three-phase analysis. Firstly, this study used Taguchi's orthogonal array to evaluate the influence of the control factors and identify the important factors influencing quality characteristics. Secondly, all normalizing experiment variables ranked the grey relational grades of multi-quality characteristics. Finally, we integrated the Taguchi method and the entropy weights by using GRA to establish entropy weight-based grey relational values.

The observations were fourfold as follows. Firstly, follow the previous studies of general quality of concrete 
blended with waste solar PV cells. The use of ground solar cells on the mechanical properties and durability of cncrete had been investigated. This research attempts further to invetigae the quality of alkali activated concrete conaining the ground amorphous silicon solar cells. We adopted both Taguchi method and GRA to calculate the equal and entropy weight-based grey relational grades of GRA. Secondly, the ranking in grey relational grades of multi-quality characteristics has been calculated. It can be seen that these two types of ranking are slightly different to each other for ranking 8th and 9th even with contrasting weight calculations. Thirdly, the optimal results of the both weights occurred in the first experiment of the grey relational grades. Finally, both grey relational grades resulted from equal and entropy weights represent the multi-quality characteristics which can be used for a comprehensive assessment like the weighted grey-Taguchi method, a next study.

\section{References}

1. J. Provis and J. van Deventer, Geopolymers: structures, processing, properties and industrial applications, Woodhead Publishing Ltd., Oxford, UK, 2009

2. L.W. Teng, R. Huang, H.M. Hsu, A. Cheng, J.R. Chang and P.H. Yu, Strength Quality Research of Cement Mortar Blended with Solar PV Cells, Adv. Mater. Res. 1025-1026 (2014)1025-1030

3. S.C. Chen, R. Huang, H.M. Hsu, L.W. Teng and Y.P. Lai, Durability Quality Research of Cement Mortar
Containing Solar PV Cells, Adv. Mater. Res. 10251026 (2014)1020-1024

4. S.C. Chen, R. Huang, H.M. Hsu, J.R. Chang and L.W. Teng, Strength Quality Research of Concrete Blended with Solar PV Cells, Adv. Mater. Res. 1061-1062 (2015)392-395

5. E. Ozbay, A. Oztasb, A. Baykasogluc and H. Ozbebekd, Investigating mix proportions of high strength self compacting concrete by using Taguchi method, Constr. Build. Mater. 23(2009)694-702

6. C.Y. Chang, R. Huang, P.C. Lee and T.L. Weng, Application of a weighted Grey-Taguchi method for optimizing recycled aggregate concrete mixtures, Cem. Concr. Compos. 33(2011)1038-1049

7. Y.S. Tarng, S.C. Juang and C.H. Chang, The use of grey-based Taguchi methods to determine submerged arc welding process parameters in hard facing, J. Mater. Process. Technol. 128(2002)1-6

8. L.K. Pan, C.C. Wang and S.L. Wei, Optimizing multiple quality characteristics via Taguchi methodbased Grey analysis, J. Mater. Process. Technol. 182 (2007)107-116

9. S.Y. Zou, R. Huang, M.C. Chi and H.M. Hsu, Factors Affecting the Effectiveness of Inorganic Silicate Sealer Material through Multi-Quality Characteristics Materials, 6(3)(2013)1191-1204

10. W.K. Chan and T.K.L. Tong, Multi-criteria material selections and end-of-life product strategy: Grey relational analysis approach, Mater. Design 28(5) (2007)1539-1546 